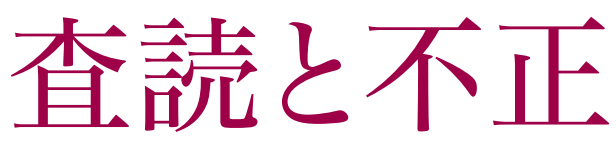

\title{
Peer review and fraud
}

Nature Vol.444(971-972)/21/28 December 2006

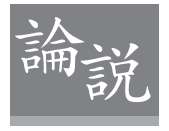

論文の審査過程に関して Science 誌の外部調査委員会が示した評価、また Nature が昨年試みた公開査読の 取り組みの結果から、科学誌のむずかしさが浮き彫りになった。

黄禹錫（ファン・ウソク）教授たちのヒト胚性幹細胞に関する 2 本の論文でライバルのS Sience 誌がダメージを受けたことに Nature が喜んでいるという話があるとすれば、それはまったくの 見当違いだ。もし、同じ論文がNatureに投稿されていたとすれば、 それらはやはり、Natureに揭載されていたかもしれないのである。

Science 誌が依頼した第三者による調査委員会 (Natureの米 国編集責任者 Linda Miller もメンバーとして加わった）は2006 年 12 月初め、件の論文掲載にあたり同誌が払った一般的な注意 レベルは妥当なものだったとの結論を出した。同委員会はそのう えで、審査過程で挙げられた懸案事項にはさらに疑いの目をもっ て注意を払うべきだったとも述べている。しかし、後からあれこ れいうのは簡単なことであり、著者と編集者との間にある程度の 信頼関係が必要とされる現状の中で、どの科学誌にとっても、あ る種の懸念がある場合にそれをどこまで追求するべきかどうか、 十分に見極められていたとはいい切れない。

調査委員会が今後向き合っていくことになるのは、まさにこの 信頼の度合いの問題だ。不正事例が実際に審査過程をすり抜け たという事実、また、科学界に対する一般の信頼を失ってはなら ないとの思いから、政策や公衆衛生、気候変動などに直接関連す るような、一般への影響が大きい論文に対し、科学誌各誌は論文 の精査とリスク評価を強化すべきだと委員会は提唱している。さ らに委員会では、生デー夕をより重視していくこと、共著者ひと りひとりの論文への貢献度を明確にすることも提案された。

こうした取り組みを進める必要があるのはNatureにとっても同 じであり、問題に共に取り組もうというScience 誌からのよびかけ に、私たちはすでに応じている。重要なのは、編集者と査読者が、 不正リスクに対する実際的感覚を磨くことだ。不正の確率を明示 的に分析しようという細心のリスク評価を実際に行うのは、口で いうょりはるかにむずかしい。リスク因子の基本的なチェック項 目を挙げていくことはできる。しかし、例えばソウル国立大学の 論文やヒト胚性幹細胞の論文を特別扱いし、ほかの論文よりも審 査のハードルを上げることは、けっして正しいとはいえないだろう。

一方で私たちは、主要な論点は必ず厳密なデー夕と論証に裏 打ちされたものであることをすでに著者たちに求めてきた。にも かかわらず、人々の耳目を引く一方で問題点も多い論文が、時折 包囲網をかいくぐってしまうのが、残念ながら現実だ。これらに
対しては、編集者がより一層の注意を払っていくしか方法はない。 Nature および各 Nature 姉妹誌は、論文に対する著者ひとり ひとりの貢献度を明確にするよう求めており、このよびかけはこ こ 1 年で著者の間にも広く浸透してきた。事実、資金提供機関 からも好評を得ている。私たちは現在、この取り組みをすべての 投稿論文に義務づけるべきかどうか決定するための調査を計画 しており、読者のみなさまもぜひ意見を寄せていただきたい。

また、査読過程がさらに一般に開かれたものであれば黄教授 の不正は発見され得たかどうかとの問いは、興味深いところで ある。しかし今のところ、公開査読に対する関心は小さく、現 状の公開査読の試みでは、結局のところ不正は見破れなかった だろう。少なくとも、Natureが試しに行った公開査読の取り組 みからは、そう結論される（このテーマに関するオンライン討論 は www.nature.com/nature/peerreview/debate/nature05535. html を参照されたい)。

この公開査読の試みでは、通常の査読と並行して、著者が選 択すれば、査読段階の論文原稿をオンラインにアップし、一般 からの意見を受け付けられるようにした。最終的に、5\%の著者 がこの選択肢を選んだ。受けた意見に何らかの価值を見いだし た著者は多かったが、そもそも数が少なく、編集者にとっては論 文を受理するかどうかを左右するほどのものにはならなかった。

しかし、今回の試みは対照試験ではなく、公開査読の制度が いつの日か受け入れられるようになるとの仮説を棄却するもので はない。しかし、研究者と非公式に交わす対話の中でも感じるこ とだが、今回の結果は、研究者の多くが多忙であること、またキャ リアにどうかかわってくるかがみえないなかで、Nature のウェブ サイトなどの場にアクセスし、研究仲間の仕事に対する批判的評 価を本名で書き込むことのむずかしさを示している。

査読のもう 1 つの形態に、論文揭載後の研究の再現性をめぐつ て行われるやりとりがある(再現ができない、という場合もある)。 この種の討論を学会でのゴシップに留めずに開かれたものとする には、編集の介入を最小限にした個々の意見を、研究者仲間が 互いに述べられるフォーラムが必要となる。Nature に寄せられ る論文に対して、研究者たちは揭載前の論文よりも正式な掲載 後のもののほうが実際にコメントしやすいのだろうか。2007 年 に私たちはこの機能を導入し、その答えを知るつもりである。 